\title{
Harmonization of Regulation on Land Acquisition For Infrastructure Development with Public-Private Partnership Scheme In Indonesia
}

\author{
Suhadi \\ Faculty of Law, Universitas Negeri Semarang (UNNES), Indonesia \\ Email: suhadi@mail.unnes.ac.id
}

\begin{abstract}
Regulations on land acquisition for infrastructure development for public purposes built with public-private partnership schemes have not been harmonized. In regulations on public-private partnership in infrastructure development, land acquisition is organized by the government, including land acquisition planning documents. The location of land for development has been established before the procurement of Private Enterprise. In the regulation on Land Procurement for Development in the Public Interest, private business entities that are authorized by the government are categorized as agencies that require land. Consequently, this private enterprise prepares the land acquisition plan documents and can carry out land procurement directly through land purchase, exchange, or other means agreed by the entitled party with a private business entity. To provide legal certainty of land acquisition for infrastructure development for public interest built with public-private partnership scheme, it is necessary to harmonize the regulation based on Indonesia's land law system, based on Law No. 2 of 2012, land procurement organized by the Government.
\end{abstract}

Keywords - land acquisition, infrastructure development, public-private partnership

\section{INTRODUCTION}

One of the policies of the Government of Indonesia to realize an adequate and sustainable infrastructure is to involve the participation of private enterprises in infrastructure development. [1] One important factor in infrastructure development is the procurement of land to be used as a development site. [2] Badan Perencanaan Pembangunan Nasional Republik Indonesia (The National Development Planning Agency of the Republic of Indonesia) estimates the need for land for infrastructure development of 140,704 hectares. The land will be used for the construction of waste processing place, drinking water, energy and electricity facilities, railways, toll roads, airports, ports, dams, and public new municipalities. [3] Land for infrastructure development is can't all be fulfilled from land controlled by the state, [4] but will also be sufficient from the land owned by individuals. In Indonesian land law, acquisition of land from individual land is called land acquisition. In the context of infrastructure development with public-private partnership schemes, on the one hand there are regulations governing public and private partnerships in infrastructure provision, on the other hand, there are regulations governing land procurement for development for the public good. The status of the party that will carry out development, government or private, determines how the land is acquired.

This paper aims to discuss the land acquisition for the construction of infrastructure built with the scheme of public-private partnership. There is a lack of regulatory synchrony as well as the implementation of regulation on land acquisition for infrastructure development built with public-private partnership schemes.
This paper uses Central Java Power Plant $2 \mathrm{X}$ 1,000 MW in Batang Regency, Central Java, Republic of Indonesia (CJPP Batang) as a case of analysis. CJPP Batang is a pilot project of infrastructure development with a public-private partnership scheme, and includes a national strategic project part of The Master Plan Acceleration and Expansion of Indonesia's Economic Development.

To discuss land acquisition for infrastructure development built with public-private partnership schemes, this paper is consist of : (1) Infrastructure Development with Public-Private Partnership Scheme in Indonesia (2) Land for CJPP Batang development, (3) Harmonization of land acquisition regulations for infrastructure development with public and private partnership schemes.

\section{RESEARCH METHOD}

The research method used in this research is normative law research [5] and case study. [6] Sources of data in this study are secondary data in the form of primary legal materials, secondary legal materials, and tertiary legal materials. [7] Data analysis was done by using qualitative analysis.

\section{RESULT AND DISCUSSION}

\section{A. Infrastructure Development with Public-Private Partnership Scheme in Indonesia}

The Global Competitiveness Index (GCI) report 2017-2018, ranked Indonesia 36th out of 137 countries with a score of 4.7. This ranking is better than the year 2016-2017, where Indonesia is ranked 41 out of 138 countries with a score of 4.5. GCI Indonesia with a score 
of 4.7 is the highest score for six years. [8] Although Indonesia's ranking trend strengthened, but when viewed from the supporting pillars, there are still weak pillars, including infrastructure pillars. On the infrastructure pillar as the second pillar of GCI, Indonesia is ranked 52 out of 137 countries with a score of 4.5. Even from the World Economic Forum's Executive Opinion Survey, the inadequate supply of infrastructure is one of the most problematic factors for doing business. [8]

The policy to involve private participation in infrastructure development described by the Government of Indonesia in the 2005 Infrastructure Summit. In the 2005 Infrastructure Summit, the Government of Indonesia makes a projection of the need for funding in infrastructure development for five years (2005-2009) of IDR.1.305 trillion. The allocation of government funds for infrastructure development is only around IDR.495 trillion or $38 \%$ of the needs, the remaining IDR.910 trillion or $62 \%$ is expected to be fulfilled through a public-private partnership (PPP) project. [9] Indonesia's economic growth post the Asian financial crisis has increased the need for infrastructure investment, and the Government of Indonesia has not yet been able to fund it entirely. PPP is clearly useful and the Government of Indonesia is targeting to attract private investment in the infrastructure sector by IDR.978 trillion in the period 2010-2014. [10] With the current fiscal capacity, Indonesia will have difficulty in building infrastructure if only using government funds alone. The percentage of use of government funds in new infrastructure development is in the range of $4 \%-5 \%$ of GDP. Public and private partnerships are an option that must be developed, especially for infrastructure with high financial returns, such as power generation, so that the government can focus more on building commercially unfeasible but socioeconomic infrastructure that is needed by the community. [11] Public and private partnerships are needed, among others, due to limited government funds, inadequate infrastructure both in terms of quantity and quality, and the skills (technology) owned by the private sector. [12]

CJPP Batang is the development of electricity infrastructure with Public Private Partnership (PPP) scheme. The PPP CJPP Batang project is the first largescale PPP showcase project with investment value of more than IDR.54 trillion, as well as the first PPP project implemented under Presidential Regulation no.67 Year 2005 on Government Cooperation with Business Entities in Infrastructure Development. The purpose of government and private cooperation in infrastructure development are:

a. Sufficient financing needs in the provision of infrastructure through private fundraising

b. Increase the quantity, quality and efficiency of service through healthy competition

c. Improve the quality of management and maintenance in infrastructure provision

d. Encourage the use of the principle of users paying for services received. [13]
In relation to public and private cooperation in infrastructure development, the National Legal Development Board explains that "PPP scheme is a cooperative agreement between a government agency and a private entity, where (a) a private party executes some government function for a certain period, (b) the private party receives compensation for the execution of the function, either directly or indirectly (c) the private sector is responsible for the risks arising from the exercise of such functions, and (d) government facilities, land or other assets may be assigned or used by private parties ".[14]

\section{B. Land for the Development of Central Java Power Plant in Batang Regency}

The construction of the CJPP Batang as a whole requires 314.4 hectares of land. The land will be used for construction and operation of Power Block, construction of SUTET $500 \mathrm{KV}$ network, construction of substations, and construction of access road to power block and fly over. Of the total land requirement of 314.4 hectares, the most widespread land is used for the construction of a 226.4 hectare power block located in the Ujungnegoro and Karanggeneng villages, Kandeman's Ditrict and Ponowareng Village, Tulis District of Batang.[15]

Table 1. Land Requirement for Batang PLTU Construction

\begin{tabular}{|c|c|c|c|}
\hline No & Utilization & Extent & Location \\
\hline 1 & $\begin{array}{l}\text { Development and } \\
\text { operation of Power } \\
\text { Block }\end{array}$ & $226,4 \mathrm{Ha}$ & $\begin{array}{l}\text { Ujungnegoro Village } \\
\text { Karanggeneng Village } \\
\text { Ponowareng Village }\end{array}$ \\
\hline 2 & $\begin{array}{l}\text { Construction of } \\
\text { SUTET } 500 \mathrm{KV} \\
\text { network }\end{array}$ & $61,4 \mathrm{Ha}$ & $\begin{array}{l}\text { Karanggeneng Village } \\
\text { Wonookerso Village } \\
\text { Ponowareng Village } \\
\text { Kenconorejo Village } \\
\text { Simbang Jati Village } \\
\text { Beji Village } \\
\text { Tulis Village } \\
\text { Wringin Gintung Village }\end{array}$ \\
\hline 3 & $\begin{array}{l}\text { Construction of } \\
\text { substations }\end{array}$ & $25 \mathrm{Ha}$ & $\begin{array}{l}\text { Simbang Jati Village } \\
\text { Beji Village } \\
\text { Tulis Village }\end{array}$ \\
\hline 4 & $\begin{array}{l}\text { Construction of } \\
\text { access road to } \\
\text { Power Block and } \\
\text { Fly Over } \\
\text { Total Land } \\
\text { Requirement }\end{array}$ & $314,4 \mathrm{Ha}$ & $\begin{array}{l}\text { Karanggeneng Village } \\
\text { Ponowareng Village }\end{array}$ \\
\hline
\end{tabular}

Source: Announcement of AMDAL PLTU Development Central Java 2 X 1000 MW Batang District Central Java Province, on October 8, 2012 and October 15, 2012.

Acquisition of land for the construction of CJPP Batang obtained by two ways, namely the sale and purchase of land between PT. Bhimasena Power Indonesia with landowners, on a location permit basis, and land revocation through land acquisition activities. Based on the way of land acquisition, the construction of CJPP Batang was initially a private project, and not as a public development project undertaken by the government. Because PLTU Batang is categorized as a private project, the land for CJPP Batang is obtained based on location 
permit through direct buying and selling method between landowner and PT. Bhimasena Power Indonesia.

Land acquisition for Batang plant construction through land acquisition is based on Central Java Governor Decree Number 590/35 Year 2015 About Approval of Stipulation of Land Acquisition Land Location Area of 125,146 m2 Construction of Central Java Coal-Fire Power Plant 2 X 1000 MW in Batang Regency Central Java Province. In the Decree of the Governor of Central Java Number 590/35 Year 2015 it is clearly stated that the determination of the location given to the Unit Induk Pembangunan VIII PT. PLN (Persero) is now the Unit Induk Pembangunan Jawa Bagian Timur dan Bali (JBTB) II PT. PLN (Persero). This means that the agency that needs land related to the remaining land is no longer PT. Bhimasena Power Indonesia but PT. PLN (Persero). The consequence of this is that the budget for land acquisition through land acquisition is the responsibility of PT. PLN (Persero) and land will be utilized by PT. PLN (Persero). The research data shows that the land acquired through the procurement of the remaining land area of $125,146 \mathrm{~m} 2$ is located in three villages, namely Karanggeneng Village and Ujungnegoro Village, Kandeman District, and Ponowareng Village, District of Tulis Batang Regency. [15]

\section{Harmonization of Land Acquisition Regulation for Infrastructure Development with Public-Private Partnership Scheme}

Regulation on land revocation in Indonesia is Law No. 2 of 2012 on Land Procurement for Development for Public Interest. In Law Number 2 Year 2012 stipulated that the government can take over private land for reasons of public interest. The regulation on the acquisition of private land for public interest is derived from Article 6 and Article 18 of Law No. 5 of 1960 on Basic Agrarian Principles (UUPA) which is the implementation of Article 33 Paragraph (3) of the 1945 Constitution of the State of the Republic of Indonesia.

Based on Law No. 2 of 2012, the construction of power plants including development for the public interest. Public procurement of land for public purposes is held by the Government. Institutions that need land for public purposes are state institutions, ministries and nonministerial government agencies, provincial governments, district / city governments and state / state-owned Legal Entities that receive special government assignments

Construction of CJPP Batang with a scheme of public- private partnership is based on Presidential Regulation No. 67/20005. The scope of Presidential Regulation No. 67/20005 is the cooperation between the government and the private sector in infrastructure development. In the context of this research which is cooperation between PT. PLN (Persero) and PT. Bhimasena Power Indonesia is buying and selling electricity. The main business of PT. Bhimasena Power Indonesia is selling power to PLN with 25 years contract with Build, Own, Operate, Transfer (BOOT) scheme.

Based on Article 23 paragraph (2) of Presidential Regulation 67/2005, in the case of infrastructure provision implemented by private land acquisition, the amount of implementation guarantee can be determined by taking into account the expenses incurred by the private sector for the land acquisition. This guarantee of implementation is one of the provisions contained in the cooperation agreement. Thus, the acquisition of land is done by the private sector, but the financing can be taken into account in the sale and purchase agreement. In its development, land acquisition for development activities carried out under the scheme of public and private cooperation, based on Presidential Regulation No. 38 of 2015 shall be held by the government. Land acquisition planning documents up to the issuance of land acquisition location shall be conducted by the Government. Thus, prior to the establishment of the development executor, the location of land acquisition is certain.

Private land procurement for infrastructure development for public purposes does not comply with Law No. 2 of 2012. Land acquisition for infrastructure development must be carried out by the government. However, in its development, based on Presidential Regulation No. 148 of 2015, private parties that have the power of the government are categorized as agencies that require land, which makes land procurement planning. In this context, there is a disharmony of regulation on land acquisition for infrastructure development built with public-private partnership schemes. With reference to the legal system, it is necessary to harmonize the presidential regulations governing land acquisition and presidential regulations governing public and private cooperation in infrastructure development.

Regulation of land acquisition for infrastructure development with public-private partnership scheme must be returned to Law Number 2 Year 2012. Presidential Regulation No. 148 Year 2015, which include the private sector as an agency requiring land needs to be reviewed. The private sector is not an institution that needs land. Agencies that require land are ministries or state-owned enterprises that receive special assignments from the Government. In the context of Batang PLTU development, the agency that needs land is PT. PLN (Persero). A review of Presidential Regulation No. 148 of 2015 is necessary to harmonize with Presidential Regulation No. 38 of 2015.

\section{CONCLUSION}

Regulations on land acquisition for infrastructure development for public purposes built with public-private partnership schemes have not been harmonized. In regulations on public-private partnership in infrastructure development, land acquisition is organized by the government, including land acquisition planning documents. The location of land for development has been established before the procurement of Private Enterprise. In the regulation on Land Procurement for Development in the Public Interest, private business entities that are authorized by the government are categorized as agencies that require land. Consequently, this private enterprise prepares the land acquisition plan documents, and can carry out land procurement directly through land purchase, 
exchange, or other means agreed by the entitled party with a private business entity.

To provide legal certainty of land acquisition for infrastructure development for public interest built with public-private partnership scheme, it is necessary to harmonize the regulation based on Indonesia's land law system, based on Law No. 2 of 2012, land procurement organized by the Government.

\section{REFERENCES}

[1] Peraturan Presiden Nomor 38 Tahun 2015 tentang Kerjasama Pemerintah Dengan Badan Usaha Dalam Penyediaan Infrastruktur. Sebelum Peraturan Presiden Nomor 38 Tahun 2015, regulasi yang mengatur partisipasi badan usaha swasta dalam penyediaan infrastruktur di Indonesia adalah Peraturan Presiden Nomor 67 Tahun 2005, Peraturan Presiden Nomor 13 Tahun 2010, Peraturan Presiden Nomor 56 Tahun 2011, dan Peraturan Presiden Nomor 66 Tahun 2013.

[2] Sudjarwo Marsoem, Wahyono Adi dan Pieter G. Manoppo. (2015) Pedoman Lengkap ganti Untung Pengadaan Tanah Memetakan Solusi Strategis Pengembangan Infrastruktur di Indonesia. (Jakarta: Renebook)

[3] Kementerian Perencanaan Pembangunan Nasional/Badan Perencanaan Pembangunan Nasional. Ringkasan Rencana Pembangunan Jangka Menengah Nasional (RPJMN 20152019). (2014)

[4] Tanah negara adalah tanah yang dikuasai oleh negara, baik secara langsung maupun tidak langsung. Tanah yanh dikuasai langsung oleh negara adalah tanah yang belum dilekati dengan hak-hak tanah individual, sedangkan tanah negara tidak langsung adalah tanah negara yang berasal dari tanah-tanah individual yang telah dilepaskan oleh pemegangnya

[5] Normative legal research examines laws that are conceptualized as norms or rules that apply in society and become the reference of everyone's behavior. The applicable legal norm is a positive legal norm written formation of legislation and written legal norms established by the judiciary, as well as written legal norms made by interested parties. See Abdulkadir Muhammad, 2004, Hukum dan Penelitian Hukum, Bandung, Citra Aditya Bakti, p. 48

[6] Robert K. Yin. Studi Kasus Desain dan Metode (terjemahan M. Djuazi Mudzakir) dari judul asli Case Study Research: Design and Methods. (Jakarta: RadjaGrafindo Persada, 2015), p. 1

[7] Primary legal materials, secondary legal materials, and tertiary legal materials are the legal literature material that is distinguished from the point of binding force. See Soerjono Soekanto, Sri Mamudji, Penelitian Hukum Normatif Suatu Tinjauan Singkat, Jakarta, RajaGrafindo Persada, p. 33

[8] Klaus Schwab. 2017. The Global Competitiveness Report 2017-2018. Geneva. World Economic Forum, p 148

[9] Bambang Susantono. Memacu Infrastruktur di Tengah Krisis. (Jakarta: Pustaka Bisnis Indonesia, 2010), hlm 147

[10] Mike Crosetti. "Era Baru Kerjasama Pemerintah Swasta" dalam Jurnal Prakarsa Infrastruktur Indonesia Edisi 3 Juli 2010, hlm 13

[11] Bambang Susantono. Memacu Infrastruktur di Tengah Krisis. (Jakarta: Pustaka Bisnis Indonesia, 2010), hlm 8

[12] Dwinanta Utama. " Prinsip dan Strategi Penerapan Public Privat Partnership Dalam Penyediaan Infrastruktur Transportasi” dalam Jurnal Sains dan Teknologi Indonesia Vol 12 No.3 Desember 2010, hlm 146

[13] Presidential Regulation no. 67 of 2005 on Public Private Partnership in Infrastructure Development.

[14] Legal Study Team on Implementation of Public Privat Partnership (PPP) System In Electrical Energy Development Project. Legal Study Report on Implementation of Public Privat Partnership System (PPP) In Prep, Electrical Energy Development (National Legal Development Board of the Ministry of Justice and Human Rights 2015) p11

[15] Suhadi and Ridwan Arifin. (2018). The Role Of Judicial Institutions In The Context Of Land Acquisition For The Construction Of Coal-Fired Power Plant (Pltu) Batang Indonesia: A Discourse Of Legal Functions. South East Asia Journal of Contemporary Busines, Economics and Law, Vol 15, Isuue 4 (April) 2018 p 13 